\title{
Łódzkie biograficzne konferencje andragogiczne
}

Środowisko łódzkich andragogów w sposób systematyczny, od 11 lat, podejmuje działania mające na celu rozwój podejścia biograficznego w badaniach andragogicznych. Służą temu konferencje biograficzne oraz seria wydawnicza.

Konferencje są zorganizowane przez Zakład Andragogiki i Gerontologii Społecznej Uniwersytetu Łódzkiego, odbywają się pod przewodnictwem prof. nadzw. dr hab. Elżbiety Dubas, a wśród sekretarzy konferencji należy wymienić: dr Joannę Stelmaszczyk, mgra Wojciecha Świtalskiego, dr Annę Gutowską i dra Arkadiusza Wąsińskiego.

Genezy projektu „Biografia i badanie biografii” można poszukiwać w konferencji naukowej, połączonej z zajęciami warsztatowymi, nt. „Biograficzność w edukacji dorosłych. Warsztaty młodych andragogów” zorganizowanej z inicjatywy dr Joanny Stelmaszczyk w 2007 r. To pionierskie spotkanie kładło nacisk na warsztat badawczy andragogów zajmujących się badaniem biografii. Z biegiem lat spotkania naukowe obejmowały głównie wystąpienia o charakterze referatowym oraz komunikaty z badań, niemniej propozycje warsztatów zawsze były przez organizatorów włączane do programu obrad.

Kolejne lata przynosiły rozwój refleksji i badań skoncentrowanych wokół biografii. Rosła liczebność zgłoszeń zarówno osób chcących wysłuchać wystąpień konferencyjnych, jak i tych, którzy przygotowali referaty, co zaowocowało stałą praktyką dwudniowych (a nie jak początkowo jednodniowych) spotkań. Wśród biorących udział można wskazać zarówno naukowców o uznanym dorobku naukowym, jak i młodych badaczy stojących u progu swoich karier naukowych: doktorantów i studentów. Wśród reprezentowanych instytucji znalazły się ośrodki ze wszystkich województw z całej Polski. Łódzka Konferencja Biograficzna skupia głównie andragogów i pedagogów silnie związanych z problematyką edukacji dorosłych, niemniej wśród uczestników można również odnaleźć przedstawicieli innych dyscyplin i dziedzin nauki: psychologów, antropologów, socjologów, filozofów czy reprezentantów nauk o zdrowiu.

\footnotetext{
* Uniwersytet Łódzki, Wydział Nauk o Wychowaniu, Zakład Andragogiki i Gerontologii Społecznej.
} 
Konferencje dotychczas odbywały się co roku, w lutym. Po przerwie w 2018 r. będą realizowane w cyklu dwuletnim. Kolejna więc konferencja zaplanowana jest na rok 2019. Następujące po sobie odsłony konferencyjne każdorazowo dotykały w swojej problematyce zagadnień związanych z badaniem biografii, silnie uwzględniając konteksty andragogiczne, tj. dotyczące edukacji i uczenia się człowieka dorosłego, za każdym razem w nieco inny sposób, sygnalizowany w tytule konferencji. Poniżej przedstawiono wykaz dotychczas zrealizowanych spotkań:

- 2007 - I Łódzka Konferencja Biograficzna z cyklu Biografia i badanie biografii „Biograficzność w edukacji dorosłych. Warsztaty młodych andragogów”;

- 2008 - II Łódzka Konferencja Biograficzna z cyklu Biografia i badanie biografii „W obszarze zainteresowań poznawczych i kompetencji praktycznych andragoga";

- 2009 - III Łódzka Konferencja Biograficzna z cyklu Biografia i badanie biografii „Uczenie się z własnej biografii”;

- 2010 - IV Łódzka Konferencja Biograficzna z cyklu Biografia i badanie biografii „Uczenie się z biografii Innych";

- 2011 - V Łódzka Konferencja Biograficzna z cyklu Biografia i badanie biografii „Biografie edukacyjne”;

- 2012 - VI Łódzka Konferencja Biograficzna z cyklu Biografia i badanie biografii „Typowe i wyjątkowe biografie edukacyjne”;

- 2013 - VII Łódzka Konferencja Biograficzna z cyklu Biografia i badanie biografii „Osobliwości biografii edukacyjnych”;

- 2014 - VIII Łódzka Konferencja Biograficzna z cyklu Biografia i badanie biografii „Biografie edukacyjne w kontekście całożyciowego uczenia się”;

- 2015 - IX Łódzka Konferencja Biograficzna z cyklu Biografia i badanie biografii „Czas w badaniach biograficznych”;

- 2016 - X Łódzka Konferencja Biograficzna z cyklu Biografia i badanie biografii „Przełomy biograficzne i uczenie się”;

- 2017 - XI Łódzka Konferencja Biograficzna z cyklu Biografia i badanie biografii „Stałość i zmienność w biografii. Konteksty uczenia się”.

Pokłosiem obrad konferencyjnych jest seria wydawnicza „Biografia i badanie biografii" zawierająca kolejne tomy monografii wieloautorskich. Dotąd ukazały się następujące publikacje:

- Uczenie się z (własnej) biografii, red. E. Dubas, W. Świtalski, Wydawnictwo Uniwersytetu Łódzkiego, t. 1, Łódź 2011;

- Uczenie się z biografii Innych, red. E. Dubas, W. Świtalski, Wydawnictwo Uniwersytetu Łódzkiego, t. 2, Łódź 2011;

- Biografie edukacyjne. Wybrane konteksty, red. E. Dubas, J. Stelmaszczyk, Wydawnictwo Uniwersytetu Łódzkiego, t. 3, Łódź 2014;

- Biografie i uczenie się, red. E. Dubas, J. Stelmaszczyk, Wydawnictwo Uniwersytetu Łódzkiego, t. 4, Łódź 2015. 
W przygotowaniu znajdują się dwa kolejne tomy pod red. Elżbiety Dubas i Anny Gutowskiej, w tym tom: Czas i miejsca w biografii. Aspekty edukacyjne, red. E. Dubas, A. Gutowska, Wydawnictwo Uniwersytetu Łódzkiego, t. 5, Łódź 2017, który ukaże się niebawem. 